\title{
Report of the mite Lasioseius prorsoperitrematus Abo-Shnaf, Sánchez \& Moraes, 2016 (Acari: Blattisociidae) in Brazil associated with the insect Sphenophorus levis Vaurie, 1978 (Coleoptera: Curculionidae)
}

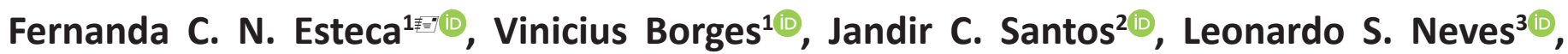 \\ Gilberto J. Moraes ${ }^{1,4}$
}

${ }^{1}$ Departamento de Entomologia e Acarologia, Escola Superior de Agricultura "Luiz de Queiroz", Universidade de São Paulo, Piracicaba, São Paulo, Brazil. ${ }^{2}$ Centre for Biodiversity Genomics, University of Guelph, Guelph, Ontario, Canada. ${ }^{3}$ Usina Iracema, Grupo São Martinho, Iracemápolis, São Paulo, Brazil. ${ }^{4}$ CNPq Researcher.

㭋Corresponding author: fernanda.esteca@usp.br

Edited by: Peterson R. Demite

Received: September 22, 2020. Accepted: October 21, 2020. Published: November 13, 2020.

\begin{abstract}
The sugarcane weevil, Sphenophorus levis Vaurie, 1978 (Coleoptera: Curculionidae), is a pest of sugarcane in Brazil. Lasioseius prorsoperitrematus Abo-Shnaf, Sánchez \& Moraes, 2016 (Acari: Blattisociidae), described from the Dominican Republic, is reported from Brazil in association with S. levis in Iracemápolis, São Paulo state. The actual role of each organism in this association needs to be verified. A key to species of Lasioseius Berlese, 1916 recorded from Brazil associated to Coleoptera is provided.
\end{abstract}

Keywords: Gamasina, phoresis, sugarcane.

The sugarcane weevil, Sphenophorus levis Vaurie, 1978 (Coleoptera: Curculionidae) is a key pest of sugarcane in Brazil, where annual losses attributed to this insect can reach 20-30 ton/ha (Degaspari et al. 1987; Dinardo-Miranda et al. 2006; Leite et al. 2012). It is usually found in four Brazilian states, namely Mato Grosso do Sul, Minas Gerais, Paraná and São Paulo (Moraes \& Ávila 2013; DinardoMiranda 2014). Eggs of this species are laid at the base of sugarcane stalks, and larvae tunnel toward the rhizome (Cerda et al. 1999). It is presently controlled with the use of pesticides, not always successfully, mainly because of the secluded behaviour of the juveniles (Zarbin et al. 2003). Promising results have been obtained in its control with the use of entomopathogenic nematodes (Giometti et al. 2011; Leite et al. 2012), but other biological control agents have been searched for. Predatory mites of the order Mesostigmata are commonly found in the soil, where they feed on a range of organisms, including other mites, nematodes, small insects and other invertebrates (Moraes et al. 2015).

Given the limited ability to disperse, predatory mites usually use insects as carriers to move between patches of ephemeral habitats, a process named phoresis, known for mesostigmatid mites of the families Laelapidae and Macrochelidae, families of a mesostigmatid group called Uropodina, and others (e.g. Hoffmann \& López-Campos 1995; Krantz 1998; Bajerlein \& Witalinski 2014). In this process, the transported organism is benefited, but it causes no damage to the carrying species.

The present study reports the first record in Brazil of the association between a species of Lasioseius Berlese, 1916 on a beetle.

A mesostigmatid mite was recently found on the body of adults of $S$. levis collected from sugarcane fields in Iracemápolis $\left(22^{\circ} 34^{\prime} 53^{\prime \prime} \mathrm{S}, 47^{\circ}\right.$ $31^{\prime} 11^{\prime \prime}$ W), São Paulo state, Brazil (Fig. 1). They were most often found between coxae I and II of the insects, but also occasionally near the base of antennae. The mites were removed from $S$. levis with a brush, mounted on microscope slides with Hoyer's medium and examined under phase (Leica, DMLB) and interference (Nikon, Eclipse 80i) contrast microscopes. Voucher specimens of the mite were deposited in the Acarology Collection of Departamento de Entomologia e Acarologia,
Escola Superior de Agricultura "Luiz de Queiroz", Universidade de São Paulo (ESALQ/USP), Piracicaba, São Paulo.

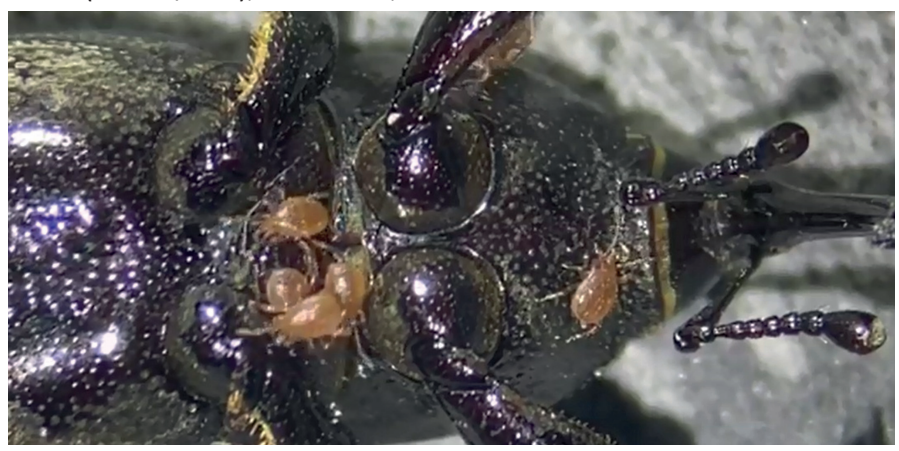

Figure 1. Lasioseius prorsoperitrematus Abo-Shnaf, Sánchez \& Moraes, 2016 on the ventral surface of Sphenophorus levis Vaurie, 1978.

The mite was identified as Lasioseius prorsoperitrematus AboShnaf, Sánchez \& Moraes, 2016 (Figs. 2-3) after a comparison with the holotype, deposited at ESALQ/USP. This species was originally described from specimens collected from coconut fruits (Cocos nucifera L., Arecaceae) in the Dominican Republic (in the Caribbean) (Abo-Shnaf et al. 2016). Nothing is known about the biology of this mite species. The sugarcane weevil was identified based on the description study (Vaurie 1978).

Preliminary observations in the laboratory showed mites to leave the carrier and move onto eggs recently laid by the latter, tapping the surface continuously, as if trying to feed, leaving the egg after 10-12 hours (Fig. 4). It is possible that the association be only phoretic, with mites riding the insect in search of their actual prey or other types of food, as fungi (Moraes et al. 2015). But it could also cause some type of damage to $S$. levis, or even attack nematodes, some of which could be pathogenic to the insect. Further studies are necessary, to demonstrate the type of relation between L. prorsoperitrematus and S. levis.

Although phoresis does not seem common for Lasioseius (Blattisociidae), other three species reported in Brazil have records 
of association with beetles (Santos et al. 2020): Lasioseius floridensis Berlese, 1916 was reported associated on host Ips avulsus (Eichhoff, 1868) (Curculionidae) (McGraw \& Farrier 1969); Lasioseius subterraneus Chant, 1963 on culture of bruchid (Bruchidae) (Walter \& Lindquist 1997) and Lasioseius corticeus Lindquist, 1971 on Dendroctonus frontalis Zimmermann, 1868 (Lindquist 1971), Ips avulsus (Eichhoff, 1868), Ips calligraphus (Germar, 1824) and Ips grandicollis (Eichhoff, 1868) (Moser \& Roton 1971).

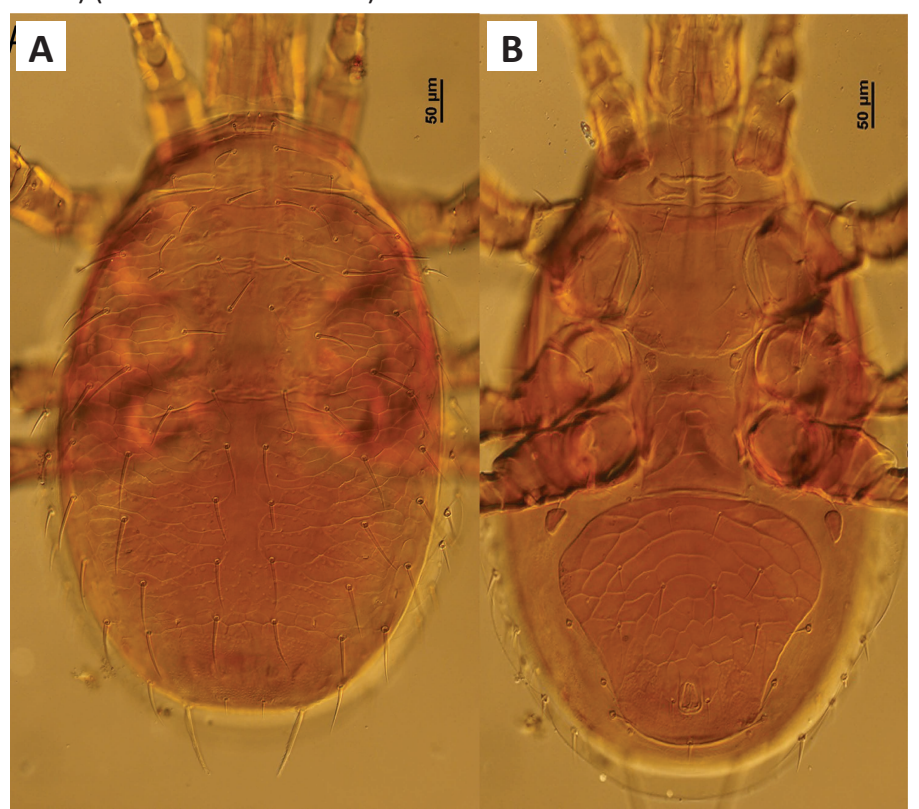

Figure 2. Lasioseius prorsoperitrematus Abo-Shnaf, Sánchez \& Moraes, 2016, adult female: dorsum (A) and venter (B) of idiosoma.

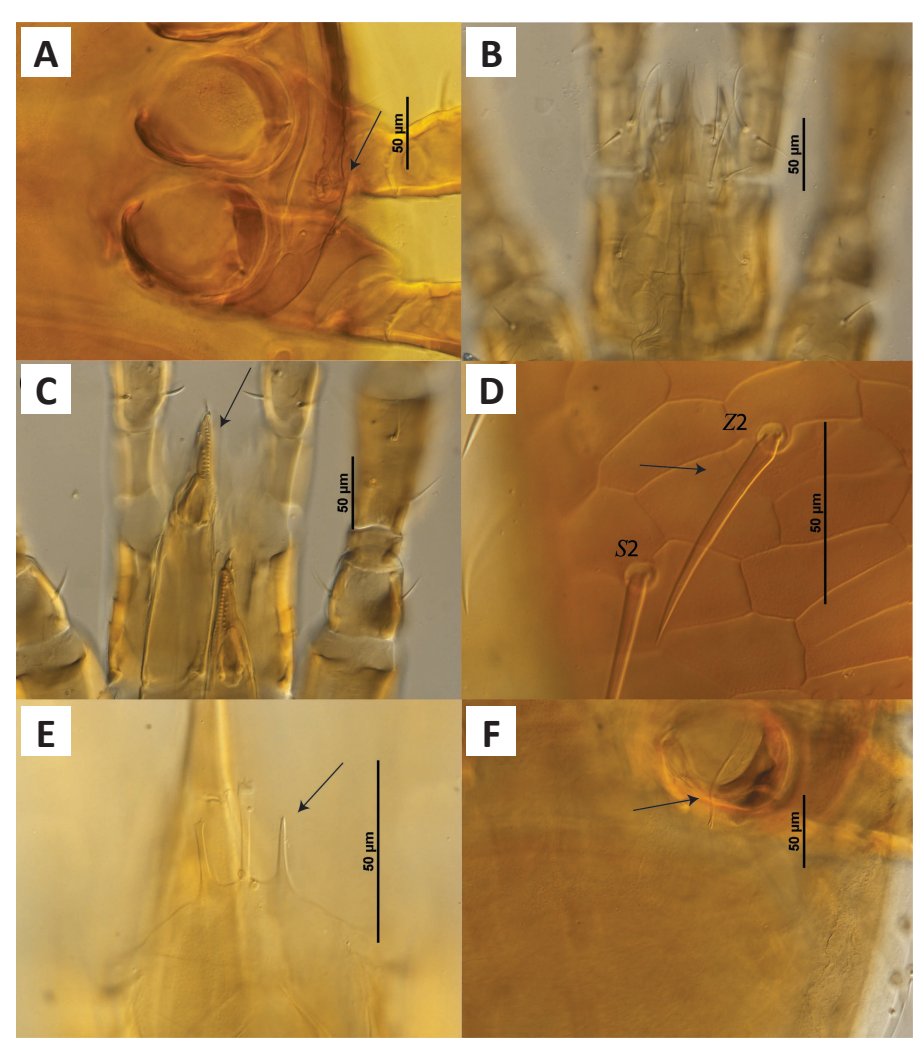

Figure 3. Lasioseius prorsoperitrematus Abo-Shnaf, Sánchez \& Moraes, 2016 posterior portion of peritreme and stigma (A); hypostome (B); chelicera (C); setae $Z 2$ and base of S2 (D); tectum (E); spermatheca (F).

The rare occurrence of phoresis in this genus suggests that these mites are well adapted to the usual changes in the niche they occupy, given the polyphagous habits of species of this group (Moraes et al. 2015).

Differences between Brazilian Lasioseius associated with beetles can be seen in the dichotomous key provided in this note.

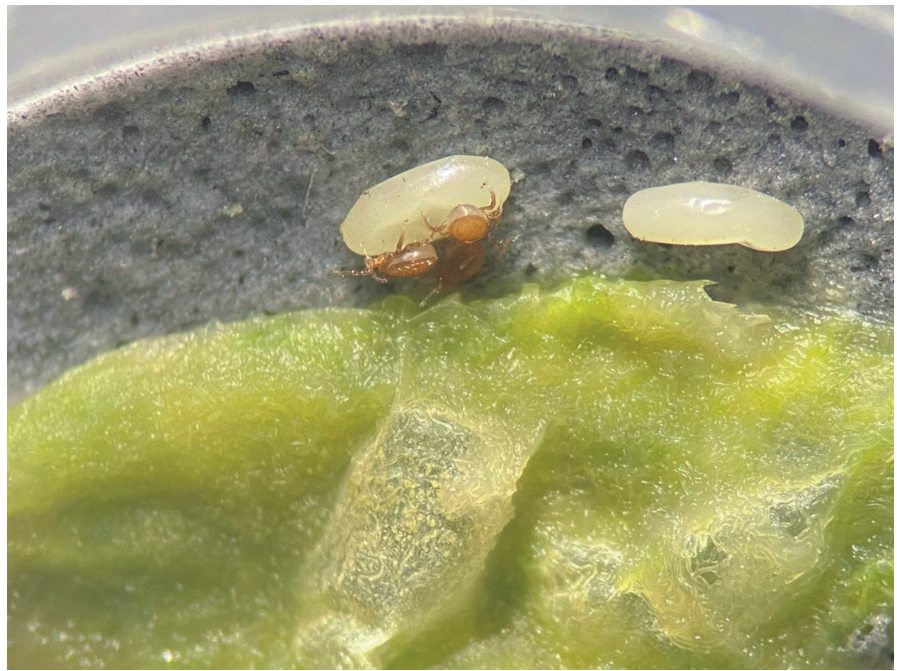

Figure 4. Lasioseius prorsoperitrematus Abo-Shnaf, Sánchez \& Moraes, 2016 moving on a recently laid egg of Sphenophorus levis Vaurie, 1978.

\section{Key to Lasioseius species recorded from Brazil in association with Coleoptera (based on females)}

1. Movable cheliceral digit with five or more teeth; posterior margin of sternal shield convex; with a pair of robust endopodal shields beside coxae III-IV ...... Lasioseius (Endopodalius) Christian \& Karg, 2006 ......... ... Lasioseius prorsoperitrematus Abo-Shnaf, Sánchez \& Moraes, 2016

$1^{\prime}$. Movable cheliceral digit usually with at most four teeth; posterior margin of sternal shield straight or concave; without robust endopodal shield beside coxae III ........ Lasioseius (Lasioseius) Berlese, 1916 .......... 2

2. Dorsal shield with seta $r 4$ short, not more than half as long as $s 4 \ldots$ Lasioseius floridensis Berlese, 1916

2 '. Dorsal shield with seta $r 4$ longer, over half as long as long as $s 4 \ldots . .3$

3. Most dorsal setae simple ...... Lasioseius subterraneus Chant, 1963

3'. Most dorsal setae tricarinate.. Lasioseius corticeus Lindquist, 1971

\section{Acknowledgments}

The authors are grateful to Maressa de Oliveira Henrique for calling their attention to association here reported.

\section{Authors' Contributions}

FCNE and LSN detected the mite in association with the sugarcane weevil. VB and JCS helped in the identification of the mite. FCNE, VB, JCS, LSN and GJM wrote the note.

\section{References}

Abo-Shnaf, R. I. A.; Sánchez, L.; Moraes, G. J. (2016) Plant inhabiting Gamasina mites (Acari: Mesostigmata) from the Dominican Republic, with descriptions of four new species of Lasioseius (Blattisociidae) and complementary descriptions of other species. Systematic and Applied Acarology, 21(5): 607-646. doi: 10.11158/ saa.21.5.5

Bajerlein, D.; Witaliński, W. (2014) Localization and density of phoretic deutonymphs of the mite Uropoda orbicularis (Parasitiformes: Mesostigmata) on Aphodius beetles (Aphodiidae) affect pedicel length. Naturwissenschaften, 101: 265-272. doi: 10.1007/s00114014-1150-x

Berlese, A. (1916) Centuria prima di Acari nuovi. Redia, 12: 19-67.

Cerda, H.; Fernandez, G.; Lopez, A.; Varga, J. (1999) Olfactory attraction of the sugarcane weevil (Coleoptera: Curculionidae) to host plant odors, and its aggregation pheromone. Florida Entomologist, 82: 
103-112.

Chant, D. A. (1963) The subfamily Blattisocinae Garman (=Aceosejinae Evans) (Acarina: Blattisocidae Garman) (= Aceosejidae Baker and Wharton) in North America, with descriptions of new species. Canadian Journal of Zoology, 41(2): 243-305.

Degaspari, N.; Botelho, N. P. S.; Almeida, L. C.; Castilho, H. J. (1987) Biologia de Sphenophorus levis Vaurie, 1978 (Coleoptera: Curculionidae) em dieta artificial e no campo. Pesquisa Agropecuária Brasileira, 22: 556-558.

Dinardo-Miranda, L. L.; Fracasso, J. V.; Cabral, S. B.; Valério, W.; Gonçalves, R. D.; Beltrame, J.A. (2006) Eficiência de inseticidas aplicados em soqueiras de cana-de-açúcar no controle de Sphenophorus levis. STAB, 24: 34-37.

Dinardo-Miranda, L. L.; Fracasso, J. V.; Costa, V. P.; Lopes, D. O. T. (2014) Dispersal of Cotesia flavipes in sugarcane field and implications for parasitoid releases. Bragantia, 73: 163-170. doi: 10.1590/ brag. 2014.023

Giometti, F. H. C.; Leite, L. G.; Tavares, F. M.; Schmit, F. S.; Batista Filho, A.; Acqua, R. D. (2011). Virulência de nematoides entomopatogênicos (Nematoda: Rhabditida) a Sphenophorus levis (Coleoptera: Curculionidae). Bragantia, 70: 81-86. doi: 10.1590/ S0006-87052011000100013

Hoffmann, A.; López-Campos, G. (1995) Género y especie nuevos de Hypoaspidinae (Acarida: Laelapidae) en un caso de foresia multiple. Anales del Instituto de Biologia, Universidad Nacional Autonoma de Mexico, 66: 33-46.

Krantz, G. W. (1998) Review Reflections on the biology, morphology and ecology of the Macrochelidae. Experimental and Applied Acarology, 22: 125-137. doi: 10.1023/A:1006097811592

Leite, L. G.; Tavares, F. M.; Botelho, P. S. M.; Batista Filho, R.; Polanczyk, R. A.; Schimidt, F. S. (2012) Eficiência de nematoides entomopatogênicos e inseticidas químicos contra Sphenophorus levis e Leucothyreus sp. em cana-de-açúcar. Pesquisa Agropecuária Tropical, 42: 40-48. doi: 10.1590/S1983-40632012000100006

Lindquist, E. E. (1971) New species of Ascidae (Acarina: Mesostigmata) associated with forest insect pests. The Canadian Entomologist, 103(7): 919-942.

McGraw, J. R.; Farrier, M. H. (1969) Mites of the superfamily Parasitoidea (Acarina: Mesostigmata) associated with Dendroctonus and Ips (Coleoptera: Scolytidae). North Carolina Agricultural Experiment Station, Technical Bulletin, 192: 1-162.

Moraes, G. C.; Ávila, C. J. (2013) Sphenophorus levis detected in Mato Grosso do Sul, Brazil. Agricultural Science Research Journals, 3(1): 36-37.

Moraes, G. J.; Venancio, R.; Santos, V. L. V.; Paschoal, A. (2015) Potential of Ascidae, Blattisociidae and Melicharidae (Acari: Mesostigmata) as biological control agents of pest organisms. In: Carrillo, D. Moraes, G. J.; Peña, J. (Eds), Prospects for biological control of plant feeding mites and other harmful organisms, pp. 33-66. Cham: Springer International Publishing. doi: 10.1007/978-3-319-150420_2

Moser, J. C.; Roton, L. M. (1971) Mites associated with southern pine bark beetles in Allen Parish, Louisiana. The Canadian Entomologist, 103: 1775-1798. doi: 10.4039/Ent1031775-12

Santos, J. C.; Demite, P.R.; Moraes, G.J. (2020) Blattisociidae Database. http://www.lea.esalq.usp.br/acari/blattisociidae. Access on: 20.x.2020.

Walter, D. E.; Lindquist, E. E. (1997) Australian species of Lasioseius (Acari: Mesostigmata: Ascidae): the porulosus group and other species from rainforest canopies. Invertebrate Systematics, 11(4), 525-547. doi: 10.1071/IT96003

Vaurie, P. (1978) Revision of the genus Sphenophorus in South America. Bulletin of the American Museum of Natural History, 2656: 1-30.

Zarbin, P. H. G.; Arrigoni, E. D. B.; Reckziegel, A.; Moreira, J. A.; Baraldi, P. T.; Vieira, P. (2003) Identification of male-specific chiral compound from the sugarcane weevil Sphenophorus levis. Journal of Chemical Ecology, 29(2): 377-386. doi: 10.1023/A:1022634012212 